\title{
PERAN BUDAYA DALAM MEMBANGUN HUBUNGAN ANTARA UMAT BERAGAMA DI SUKU TENGER
}

\author{
${ }^{1}$ M. Thoriqul Huda, ${ }^{2}$ Irma Khasanah \\ ${ }^{1}$ Institut Pesantren KH Abdul Chalim Mojokerto, ${ }^{2}$ UIN Sunan Ampel Surabaya \\ E-mail : $\underline{\text { huda90.ikhac@gmail.com }}$
}

\begin{abstract}
Indonesia is a country that has diversity in ethnicity, ethnicity, race, language, religion, and culture. However, this diversity is capable of causing conflicts both internally and externally. As with many cases that occur in Indonesia. Religion itself is a foothold, belief, and life guide, even as a scapegoat for conflicts in society. But other than the tengger tribe located in Lumajang Regency, Malang Regency, Pasuruan Regency and Probolinggo Regency, there are three religions that coexist in one village namely Islam, Hinduism and Buddhism. In the midst of pluralism, different societies of understanding and belief turned out to be able to have an attitude of tolerance and mutual respect between each other. Religious diversity is not a problem for the agrosari community to interact in carrying out daily activities. Regarding tolerance among religious people has recently become a very sticky issue among academics and the public. Local wisdom and culture are solutions to overcome this problem. Local wisdom in the Tengger tribe community is inseparable from the values of Javanese culture, as well as the cultural heritage of Majapahit which is still developing with mutual respect, tolerance, and respect for ancestral spirits and there are no striking differences in ethnicity other than differences in religious beliefs. Togetherness is manifested in the form of traditional rituals such as the Unan-Unan ceremony, Bari'an (Selamatan). Each religion has its own demands for tolerance in the Tengger tribe is ingrained, the Tengger tribe community also upholds equality and democracy in community life and respects religious leaders and dukun (sepiritual teachers) rather than administrative leaders. Because all are brothers, all families, still peaceful and harmonious, which is the mandate and ancestral heritage.
\end{abstract}

Keywords: Harmony, Interfaith Relations, Suku Tengger

\begin{abstract}
Abstrak
Indonesia termasuk Negara yang mempunyai keanekaragaman suku, etnis, ras, bahasa, agama, serta budaya. Namun, dengan keberanekaraman ini mampu menimbulkan konflik baik internal maupun eksternal. Seperti halnya kasus yang banyak terjadi di Indonesia. Agama sendiri merupakan pijakan, keyakinan, dan pedoman hidup, bahkan juga sering dijadikan kambing hitam timbulnya konflik didalam masyarakat. Akan tetapi lain dengan suku tengger yang terletak di Kabupaten Lumajang, Kabupaten Malang, Kabupaten Pasuruan dan Kabupaten Probolinggo disini terdapat tiga agama yang hidup berdampingan dalam satu desa yakni Islam, Hindu, dan Budha. Ditengah- tengah kemajemukan masyarakat yang berbeda paham serta keyakinan ternyata mampu memiliki sikap toleransi dan saling menghormati antar sesama. Keberanekaragaman agama bukanlah menjadi persoalan masyarakat agrosari untuk berinteraksi dalam melakukan aktivitas sehari- hari. Mengenai toleransi antar umat beragama akhir- akhir ini menjadi isu yang sangat mencuat baik dikalangan akademisi maupun masyarakat. Kearifan lokal dan budaya menjadi solusi untuk mengatasi masalah tersebut. Kearifan lokal yang ada pada masyarakat suku tengger tidak lepas dari nilai-nilai kebudayaan jawa, serta warisan budaya Majapahit yang masih berkembang dengan sikap saling saling menghargai, sikap toleransi, dan penghormatan pada roh leluhur dan tidak ada
\end{abstract}


perbedaan suku yang mencolok selain perbedaan keyakinan agama. Kebersamaan yang diwujudkan dalam bentuk ritual adat seperti upacara unan-unan, Bari'an (selamatan). Masing- masing agama mempunyai tuntutan sendiri toleransi di suku tengger ini sudah mendarah daging, masyarakat suku tengger juga menjunjung tinggi nilai persamaan dan demokrasi dalam kehidupan bermasyarakat serta lebih menghormati para pemuka agama dan dukun (guru sepiritual) dibandingkan pemimpin administrativ. Karena semua adalah saudara, semua keluarga, tetap tentram dan rukun yang menjadi amanah serta warisan leluhur.

Kata Kunci: Harmoni, Hubungan antar Agama, Suku Tengger.

\section{PENDAHULUAN}

Indonesia sangat memegang teguh warisan pesan leluhur yaitu semboyan "Bhineka Tunggal Ika" yang berarti meskipun terdapat suatu perbedaan akan tetapi tetap satu jua, Kerukunan ini merupakan suatu pilar paling penting sebagai pondasi masyarakat dalam memelihara kerukunan keutuhan suatu bangsa. Pondasi kerukunan yang kuat baik dari, suku, agama, bahasa, ras dan agama, maka bangsa Indonesia ini akan mudah diadu do mba serta terancam akan mengalami perpecahan. keanekagaraman agama berpotensi sangatlah kuat terhadap identitas dari masing masing agama yang akan berpotensi menimbulkan konflik. Kekompakan sendiri dipahami sebagai kondisi suatu kehidupan yang terjalin secra tentram, damai, saling menghargai antar sesama, saling menghormati, dan saling gotong royong. Kerukunan antar umat Beragama diciptakan agar tidak terjadi tegang rasa, serta permusuhan baik dari intern agama maupun dari umat beragama yang lain. Kerukunan umat beragama sendiri dapat diartikan dengan kondisi sosial dimana semua pemeluk agama dapat hidup secara berdampingan dalam satu tempat tanpa mengurangi kewajiban dan hak masing-masing pemeluk agama. Kerukunan merupakan suatu kebutuhan yang tidak dapat ditundatunda lagi.

Tercapainya suasana harmonis dalam kehidupan masyarakat. Hal ini terwujud dalam rasa saling menghormati antar pemeluk agama. Kebebasan dalam memeluk agama dan melakukan ibadah sesuai dengan keyakinan masing- masing dan tidak memaksakan keyakinan terhadap pemeluk agam lain dengan saling mempercayai antar sesama baik intern maupun eksteren pemeluk agama dengan pemerintah demi terwujudnya masyarakat yang harmonis serta bertanggung jawab untuk menjaga agama dan bangsa. ${ }^{1}$ Seperti yang sudah dijelaskan didalam al-Qur'an bahwa manusia diciptakan untuk saling mengenal,

${ }^{1}$ H.R. Djatiwijono, Dinamika Kerukunan Hidup Beragama Di Daerah (Jakarta: Maret, 1983), 5 

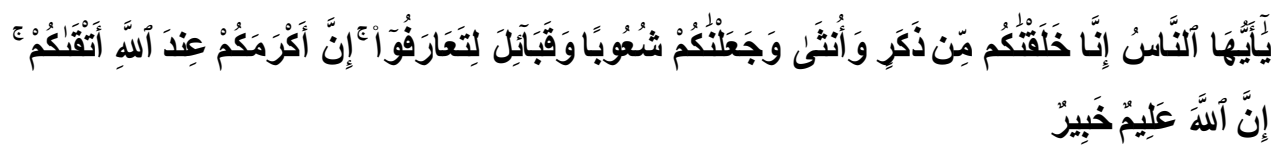

"Hai manusia, sesungguhnya Kami menciptakan kamu dari seorang laki-laki dan seorang perempuan dan menjadikan kamu berbangsa-bangsa dan bersuku-suku supaya kamu saling kenal-mengenal. Sesungguhnya orang yang paling mulia diantara kamu disisi Allah ialah orang yang paling takwa diantara kamu. Sesungguhnya Allah Maha Mengetahui lagi Maha Mengenal". ${ }^{2}$

Ayat tersebut menunjukkan adanya kerukunan dalam hidup, kerukunan yang menjadi pegangan dari masing- masing golongan agama sehingga lebih mudah dalam membangun interaksi sosial dan agama. Apabila suatu golongan agama telah berhubungan dengan baik dengan golongan lain maka Interaksi lebih mudah dalam mengembangkan hubungan kerja, dan saling gotong royong terutama dalam pelestarian tradisi masyarakat untuk membangun hubungan yang bermasyarakat dan bernegara. ${ }^{3}$ Berangkat dari gambaran diatas dapat terdapat suatu hal yang menarik untuk dikaji dan diteliti terkait kerukunan umat beragama di Suku Tengger (Suku yang hidup dan tinggal dibawah lereng Gunung Semeru, penyebarannya terdapat di empat wilayah kabupaten yakni: Kabupaten Pasuruan, Kabupaten Lumajang, Kabupaten Probolinggo dan Malang). Masyarakat suku tengger sangat menjunjung tinggi nilai keluuhuran dan sangat menghormati adat serta Dukun (Pemimpin Umat) dari pada pimpinan pemerintah.

Wujud dari menjaga kerukunan umat beragama disuku tengger yaitu dengan melakukan pelestarian tradisi kearifan lokal yang ada didaerah suku tengger menurut para dukun disana kearifan lokal ini warisan leluhur pada masa kerajaan majapahit yang masih di selenggarakan sampai sekarang. Seperti Upacara Unan-Unan, Karo- Karo, Galungan, Kasada. Pada pembahasan suku tengger ini membahas terkait kerukunan yang sering dilakukan oleh umat Hindu dan umat Islam, yaitu upacara unan- unan dan bari'an. Upacara unan- unan ini dalam kalender umat Hindu dilaksanakan sewindu sekali bukan berarti 8 tahun sekali melainkan 5 tahun sekali dalam penanggalan Hindu. ${ }^{4}$ Begitu junga dengan upaca Bari'an yang dilakukan umat Islam suku tengger satu tahun sekali sebagai bentuk ucapan rasa syukur kepada Allah atas hasil bumi yang melimpah ruah ${ }^{5}$. Tradisi- tradisi tersebut yang kerap kali mereka lakukan bersama sebagai adat serta Norma yang ada

2 Al-Quran, Surat Al Hujurat Ayat 13

3 Said Aqil Al- Munawar, Fiqh Hubungan Antar Agama, (Jakarta: Ciputat Press, 2005), 22

4 Robert W. Hefner, Hindu Javanes And Tradition Islam (Princeton: Princeton University Perss, 1985), 17

5 Mohammad Ali Hisyam, "Harmonisasi Lintas Agama Masyarakat Tengger", ISLAMICA, Vol 10, N0 01, September 2015 
disuku tengger untuk tetap saling menjaga kerukunan dan sosial dengan masyarakat suku tengger meskipun berbeda keyakinan. ${ }^{6}$

\section{HUBUNGAN ANTAR AGAMA}

Menilik ulang Indonesia ini terdapat beragam kekayaan yang berbeda disetiap daerahnya baik dari segi suku, ras, bahasa, agama serta budaya. Keberagaman ini sebagai pioner suatu bangsa dalam menciptakan kerukunan umat beragama agar lebih mudah menjalin kerjasama ${ }^{7}$, disisi agama memiliki dua dampak yaitu Sentripental (sebagai pemersatu) dan juga Sentrifugal $\left(\right.$ Pemecah $\left.^{8}\right)$. Adanya dua damapak ini yang memicu teori yang mengemukakan tentang hubungan antara umat beagama. Menjaga kerukuna umat beragama tidak perlu ditandai dengan munculnya berbagai agama, yang secara realitanya sudah terlihat bahwa setiap agama memiliki corak yang berbeda baik dari sistem kelolah kelembagaannya, keyakinan, hukum yang ditetapkan maupun penafsiarnnya.

Mukti Ali mengemukakan pemikirannya tentang "agree in disegreement". Yang beranggapan bahwa melalui konsep inilah dapat menjaga kerukunan umat beragama. Dengan cara harus meyakini bahwa agama yang dipeluknyalah yang paling benar, dan mempersilahkan pemeluk agama lain untuk mempercayai agama yg dipeluknya juga yang paling benar. Konsep saling mempercayai antar sesama inilah yang dapat mengantar negara Indonesia menjadisatu kesatuhan yang utuh tidak mudah terpecah belah $^{9}$

Keharmonisan antar umat beragama yang pertama adalah terletak pada sikap toleransi yang dibangun untuk menyikapi kerukunan yang ada. Bagi negara ini toleransi sangatlah diperlukan dalam menjaga bingkai keagamaan dilihat dari bermacam-macamnya agama yang berkembang di Indonesia tidak hanya Islam yang di akui di negara Indonesia, akan tetati juga ada lima agama lainnya seperti Hindu, Budha, Kristen, Katholik, dan Kongucu. ${ }^{10}$ Toleransi sendiri patut kita banggakan namun disisi lain juga terdapat kejenuhan dari para pemeluk agama karena secara tidak langsung

6 Joko Tri Haryonto, "Kearifan Lokal Pendukung Kerukunan Beragama Pada Komunitas Tengger Malang Jatim", ANALISA, Vol 21, No 2 Tahun 2004.

7 Mursid Ali, Plularitas Sosial Dan Hubungan Antar Agama Bingkai Kulturall Dan Theologi, Kerukunan Hidup Umat Beragama, (Jakarta: Badan Peneliti Pengembangan Agama Depag RI, 1999), 11

8 M. Mundar Soelaeman, Ilmu Sosial Dasar Teori Dan Konsep Ilmu Sosial, (Bandung: ERSCO,1987), 229

9 Mukti Ali, Ilmu Perbandingan Agama, Dialog, Dakwah Dan Misi, (Jakarta: Inis, 1997), 227-229

10 Lathifatul Izza, "Melihat Potret Harmonisasi Hubungan Antar Umat Beragama Di Indonesia”, Religi, Vol IX, No. 1, Januari 2013: 4 
toleansi sendiri dapat memunculkan adanya sikap Apologis (sikap yang digunakan untuk pembelaan keyakinan). ${ }^{11}$ Pemeluk agama mengatakan bahwa agama yang di yakinilah yang paling mempunyai sikiap toleransi kuat dari pada ajaran agama lain, dari sini akan timbul ketegangan- ketegangan baru yang bersiafat Tekstual (Tertulis), dan Kontekstual (Antropologi, Sosiologi, dan Sejarah).

Para agamawan dan politisi mengklaim berkat adanya pancasila Indonesia menjadi negara damai penuh dengan kerukunan dan sikap toleransi yang begitu tinggi. Disisi lain para pemeluk agama juga ikut bersuara, orang Islam ketika pertam kali bertemu mengucapkan "Assalmualaikum" hal ini mencerminkan bahwa Islam cinta damai, begitu juga dengan umat Kristen adalah agama keselamatan, Hindu yang berpegang teguh kepada Dharma-nya, Budha juga mengklaim agamanya jalan untuk melepaskan penderitaan, dan Konghucu juga mengkalim sebagai agama cinta. ${ }^{12}$ Melihat banyaknya wacana tesebut makna tolerasnsi perlu diadakan pembaharuan karena kerukunan sendiri sifatnya keluar bukan intern yang mengaruh kepada kerukunan masyarakat sendiri bukan intern kedalam agamanya. ${ }^{13}$

Pemerintah dalam hal ini tidak berperan sebagai Arbiter (faktor dominan yang menjadi patokan adanya kerukuna umat beragama), ${ }^{14}$ hal ini membuktikan agama bukan dibawa kekuasaan pemerintah. Karena, hubungan umat beragama di Indonesia merupakan hubungan kekeluargaan sebab negara di Indonesia ini di bentuk bukan sebagai negara agama. Begitu banyak corak agama yang dijumapai dikalangan masyarakat sosial muncul beberapa gagasan untuk terjaga keharmonsan antar umat beragama, salah satunya yaitu denagn melakukan dialog antar agama hal ini yang mendapat perhatian khusus dari para pemeluk agama.

\section{DIALOG ANTAR AGAMA}

Ditengah keberagaman agama yang ada di Indonesia dengan adanya toleransi yang begitu tinggi, salaing menghormatoi antar pemeluk agama tidak cukup maka diperlukannya adanya dialog antar agama yang memberikan pemahaman terkait pemahaman ajaran agama satu dengan agama yang lainnya. Bukan berarti menjadikan orang lain begitu yakin akan agamanya dan beralih pandangan untuk berpindah agama, dialog ini di

11 Ibid, 5

12 Ibid, 6

13 Kuntojiwo, Dari Kerukunan Ke Kerjasama, Dari Toleransi Ke Kooperasi, (Jakarta: Pustaka Hidayat, 1998), 359

14 Nurcholis Majid, Fiqih Lintas Agama Membangun Masyarakat Inklusif Pluralis (Jakarta: Yayasan Wakaf Paramadina , 2004), 199 
perlukan agar pemeluk agama lain dapat memahami ajaran yang ada dari masing- masing agama dari sinilah benih- benih sikap toleransi akan semakin kuat menjadi bangunan yang utuh.

Dialaog antar agama ini bertujuan untuk memberikan pemahaman terkait ajaran dalam kehidupan dari masing-masing agama, bukan studi akademi agama apalagi membahas semua agama dan melahirkan agama baru dan juga sedang beradu argumentasi sehingga melahirkan siapa yang menang dan yang kalah dan yang kalah wajib mengikuti ajarannya. ${ }^{15}$ Karena, dialog antar umat beragama sendiri merupakan pertemuan antara hati dan pemikiran dari para pemeluk agama yang berbeda. Dialog harus di terapkan sebagai salah satu bentuk interaksi antar umat beragama dalam menjaga kebinekaan, kebersamaan dan keharmonisan dari berbagai lapisan umat beragama baik yang berada diera global maupun plural.

Leonard Swidle berpendapat terdapat sepuluh prinsip yang harus dipegang teguh ketika sedang melangsungkan dialog antar umat beragama ${ }^{16}$. Pertama, membuat relitas perubahan dan perkembangan sesuai dengan keyakinan masing- masing. Kedua, dialog harus dihadiri oleh penganut agama yang berbeda baik intern agamanya dan pemeluk berbagai agama. Ketiga, setiap peserta dialog harus memiliki kesungguhan dalam melangsungkan dialog serta kejujuran yang terutama. Keempat, setiap peserta dialog harus bisa mendeskripsikan keyakinannya sebdiri- sendiri. Kelima, berdialog tanpa asumsi yang kukuh dan tergesa- gesa atas keyakinan yang tidak bisa diterimanya. Enam, dialog dilakuan oleh pihak yang benar- benar bisa menghormati dan memahami. Tujuh, dialog dilaksanakan atas dasar saling mempercayai. Delapan, dialog harus diikuti oleh orang- orang yang kritis yang dimaksud adalah bisa menjawab semua pertanyaan dan memperkuat keyakinan agamanya. Sembilan, peserta dialog harus memahami mitra keberagamaan agama baik dari agamanya sendiri maupun ekstern agamanya. Sepuluh, dalam melangsungkan dialog tidak boleh membandingkan ajaran agamanya dengan ajaran agama lainya.

Bentuk-bentuk harmonisasri antar umat beragama untyk menjaga kerukunan anatar umat beragama salah satunya adalah dengan melangsunggkan dialog, untuk saling mempercayai dan menghormati saja tidak cukup harus dibutuhkan pemahaman yang matang terkait agamanya sendiri maupun agama yang lain.

15 Burhanuddin Daya, Herman Leonard Beck, Ilmu Perbandingan Agama Di Indonesia Dan Belanda, (Jakarta: Inis, 1992), 208

16 Leonard Swidler, The Dialogue, Ground Rules For Interreligious Dialogue, (Davao City: Tp, 1990), 95- 98 


\section{TIGA AGAMA DI SUKU TENGGER}

Suku tenger adalah masyarakat yang tinggal dipermukiman wilayah kaki gunung Semeru dan disekitar wilayah lereng Gunung Bromo, yang terletak di Kabupaten Probolinggo, Kabupaten Pasuruan, Kabupaten Lumajang, dan Kabupaten Malang. ${ }^{17}$ Tengger diartikan sebagai Tenggiring Budhi Luhur yang berarti sifat dan budi luhur yang masih melekat dan di praktikkan sampai sekarang sebagai warisan leluhur dan hukum adat, menurut masyarakat tengger kata tengger berasal dari mitos yang beredar berasal dari kisah sepasang suami istri Roro Ateng dan Joko Seger yang pertama kali menduduki wilayah tengger. Dalam legenda, sepasang suami istri tersebut memiliki keturunan 25 anak, salah satu putranya bernama Kusuma dikorbankan menjadi Tumbal dengan dilemparkan kekawah gunung bromo demi keselamatan saudara-saudaranya. Tengger berasal dari kata Teng (Anteng) dan ger (Seger) yang berarti masyarakat yang tidak banyak tingkah dan tidak mudah terusik. ${ }^{18}$ Istilah tengger lahir dari perpaduan Roro Anteng dan Joko Seger yang menjadi cikal bakal awal mulanya pemberian daerah wilayah tengger.

Arti dari istilah tersebut tergambar dari kondisi sosial masyarakat suku tengger yang hidup secara damai, tentram, saling gotong royong, bertoleransi tinggi meskipun berbeda paham keyakinan, dan taat terhadap peraturan adat yang sudah berlaku. Sehingga tidak heran jika masyarakat Tengger masih terbilang tradisional serta menjaga tatanan budayanya serta patuh terhadap pemimpinnya (Sabda Pandhita Ratu). Taat melestarikan tradisi seperti: upaca adat, perayaan hari- hari besar, percaya akan bendabenda gaib, menghormati arwah leluhur, serta selalu mengenakan pakaian khas mereka yaitu sarung yang diikatkan dileher. ${ }^{19}$

Pada dasarnya masyarakat tengger ini adalah masyarakat yang komunal yang selalu hidup secara bersamaan dalam mewujudkan kekeluargaan yang harmonis terlihat dari toleransi yang begitu tinggi ketika melakukan rituat adat, membangun rumah secara bersamaan, bercocok tanam, menghadiri hajatan terbilang sangatlah erat dalam menjaga keharmonisan umat beragama. Karena, masyarakat tengger mempunyai norma jika mereka tidak mau hidup rukun akan dikatakan sebagai Wong Sing

17 M. Dangun, Kamus Besar Ilmu Pengetahuan, (Jakarta: Lembaga Pengkajian Kebudayaan Nusantara, 1997), 1111

18 Samandhi Widyaprakoso, Masyarakat Tengger: Latar Belakang Daerah Taman Nasional Bromo ( Jakarta: Kanisius, 1994) 28-27

19 Ibid, 29 
Ora Lumrah Atau Wong Ora Lumrah. ${ }^{20}$ Dengan kekhasan tersebut dipanggil dengan julukan Wong Tengger (warga masyarakat Tengger). ${ }^{21}$

Kebayakan dari masyarakat tengger menganggap bahwa mereka keturunan asli dari garis kerajaan Majapahit terbukti dari prasasti yang ditemukan di daerah setempat bernama Prasasti Muncan.22 Prasasti ini mengkisahkan tentang sejarah awal mulanya keberadaan suku tengger yang terukir dengan halus menggunakan tulisan Aksara Jawa Kuno disebuah batu setinggi 142,5 cm dengan lebar $22 \mathrm{~cm}$ dan panjang $102 \mathrm{~cm}$. sedangkan gunung Bromo adalah bukti tempat pengabdian mereka untuk melakukan ritual yadnya (mempersembahkan hasil bumi kepada dewa). Dalam adat suku tengger tidak mengenal adanya perbedaan kasta karena memang tidak ada pemimpin yang kuat dalam mengatur segala hal yang ada hanya Dukun (pimpinan adat). Hal ini yang menyebakan nilai spirituali yang berkembang seirinh berjalnnya waktu kian mengalami pemerosotan yang mengancam hilangnya kehidupan spiritual dan upaca adat. Tahun 1945 masyarakat suku tengger mulai semangat lagi menggali kepercayaan yang mulai hilang untuk di terapkan kembali secara mendalam. ${ }^{23}$

Wong Tengger juga memiliki tata cara dalam kehidupan seperti yang tertera didalam Sesanti Pancasetya (lima petunjuk kesetiaan) yang harus di patuhi semu lapisan masyarakat suku tengger karena tidak ada perbedaan kasta yang berkembang24 yakni: Satya Wacana (perkataan harus sama dengan perbuatan), Satya Budhaya (mentaati peraturan adat), Satya Laksana (bertanggung jawab dengan tugas yang diemban), Satya Semaya (menepati janji), Satra Mitra (setia kawan). Untuk mencapai kebahagiaan hidup Wong Tengger juga menjauhi sikap Mo Lima, Maling (mencuri), Madon (Maling Perempuan), Madat (menghisab Candu), Main (judi), Minum (Mengkonsumsi Minuman Keras), dan sekaligus wajin menjaga Wa Lima: Wasra ( cukup sandanf), Wasis (Cukup Ilmu Pengetahuan), Wisma (Memiliki Tempat yang layak), Waras ( sehat Jasmani dan Rohani), Wareg (cukup sandang).

Setelah kemerdekaan Indonesia agama yang dianut masyarakat suku tengger masih belum jelas identitas yang dianutnya yang ada mereka hanya

20 Bambang Subandrijo, Keselamatan Bagi Orang Jawa, (Jakarta: Bpk Gunung Mulia, 2000), 28

21 Neng Darol Afia, Tradisi dan Kepercayaan Lokal Bagi Beberapa Suku Yang Ada di Indonseia, (Badan Litbang Agama Departemen Ri, 1999),

22 Prassati muncang dibuat pada masa kerajaan Majapahit, masyarakat tengger pada waktu itu dinamakan Hila- Hila yang berarti tempat yang dihini oleh pertapa atau orangorang suci untuk mengabdi kepada tuhan atau dewa- dewa menurut kepercayaan orang Hindu.

23 Samandhi Widyaprakoso, Masyarakat Tengger: Latar Belakang Daerah Taman Nasional Bromo, 86

24 Ayu Sutarto, Kamus Budaya Dan Religious (Jember: Lembaga Penelitian Universitas Jember, 2008) 62. 
melaksnakan ritual adat seperti : Upacara Karo- karo, Upaca Unan- Unan, Upacara Entas- Entas, Kasodo, dan jenis ritual adat yang lainnya. Baru kesaran tahun 1973 seiring dengan perkembangan zaman, kemajuan sosial, teknologi dan norma-norma yang lahir dari pengalaman masyarakat itu sendiri, ${ }^{25}$ penyuluhan terkait pembinaan agama mulai di galakkan. Menurut ketetapan Parisada masyrakat tengger termasuk penganut Agama Budha Mahayana sesuai dengan surat keputusan No.00/PHB Jatim/Kept/III/73, pada tanggal 6 Maret 1973, setelah ditinjau ulang terkait ritual yang sering dilakukan cara ibadah dan kepercayaan- kepercayaan yang diyakini ternyata banyak mengandung ajaran yang terdapat didalam agama Hindu, hal ini diperkuat dengan dipertemukannya prasasti Walandati 26 yang terdapat di desa Walandit terketak di Pegunungan Tengger tempat Hulun Hyang (Abdi Dewa- Dewi Hindu).

Kepercayaan Animisme (Percaya akan benda- benda Goib, Roh, dan Nyawa) juga sering dilakukan masyarakat tengger seperti melakukan Selametan sebagai wujud penghormatan kepada leluhur yang mempunyai posisi penting dalam setiap peristiwa, ${ }^{27}$ dan juga sebagai bentuk rasa suyur atas hasil alam yang sudah diberikan sebagai persembahan yang diberikan kepada dewa agar dewa tidak murka. ${ }^{28}$ Ketika melakukan ritual peribadatan masyarakat tengger juga membaca Japa Mantra (doa) yang hingga pada saat ini masih dipegang teguh oleh Dukun Tengger, bagi Dukun Tengger Mantra adalah harta yang paling suci sebagai bentuk pendekatan dengan sang Hyang Widhi dan juga sebagai Tameng agar dijauhkan dari Roh- Roh jahat yang mengusik ketenangan hidup. ${ }^{29}$

Dari sinilah awal mula dilahirkannya suatu perdaban yang tidak mengenal sebuah perbedaan dalam hidup bermasyarakat, meskipun ajaran agama islam masuk jauh sesudah Hindu dan Budha berkembang di masyrakat tengger tidak ada permusuhan yang dapat memecah belahkan mereka karena masyarakat tengger sangat menjunjung tinggi dan menghargai antar sesama dan memberi kebebasan berkehendak atas setiap orang untuk memeluk dan meyakini ajaran agama yang dibawahnya. Terlihat

\footnotetext{
25 Samandhi Widyaprakoso, "Masyarakat Tengger: Latar Belakang Daerah Taman Nasional Bromo", 9

26 Prasasti Walandit adalah prasasti yang menceritakn tentang dua kejadian, yaitu larangan menagih Titiloman (iuran dalam melakukan ritual upacara) didesa keramat/ Desa Walandit sekitar tahun 1303 saka atau 1381 Masehi, yang kedua, prasasti ini juga sebgai symbol dikukuhkannya perintah dari Bathara Hyang Wekas ing Suka (Gelar Anumerta Raja Hayaman Wuruk pada tahun 1327 bulan Asada).

27 Neng Darol Afia, Tradisi dan Kepercayaan Lokal Bagi Beberapa Suku yang ada di Indonseia, 46

28 Cart. R.P. Suyono, Mitisisme Tengger, (Yogyakarta: LKiS, 2009), 25

29 Ayu sutarto, Saya Orang Tengger, Saya Punya Agama: Kisah Orang Tengger Menemukan Agamanya, (Jember: Kompyawisda, 2007), 58
} 
dari agama yang berkembang didaerah suku tengger tidak hanya ada satu agama yang dipeluk masyarakat setempat melainkan banyak agama yang berkembang disana seperti agama Hindu, agama Budha, dan Agama Islam. Keyakinan boleh berbeda namun, terkait adat dan hukum yang berlaku tidak ada perbedaan. Tolak ukur yang digunakan yaitu sikap kekeluargaan sesuai dengan norma yang ditetapkan oleh para leluhur.

Agama Hindu masuk di Indonesia sekitar abad ke-4 masehi dengan beberapa bukti peninggalannya seperti Prasasti Yupa bekas kerajaan kutai yang ada di Kalimantan Timur, tujuh bua yupa yang ditemukan ini menggambarkan bahwa pada waktu itu raja Mulawarman sedang melaksanakan yadnya pemujaan kepada Dewa Shiwa. Sedangkan diwilayah tengger sendiri ajaran agama Hindu masuk sekitar abad ke-17 yang dibawah oleh pertapa- pertapa Hindu menetap diwilayah sekitar gunung Bromo, Agama Hindu mengajarrkan arti hidup rukun baik antar sesama pemeluk agama maupun pemeluk agama yang lainnya yang telah dijelaskan didalam Kitab Weda seperti Yajur Wedha dan Atara Weda. Awal mulanya di tengger masyarakatnya mempercayai tentang penghormatan kepada roh leluhur, ketika Hindu masuk ditengger maka menyesuaikan dengan kondisi masyarkat tengger saat itu, sehingga terjalin adanya kontak budaya dan ajaran agama Hindu. Oleh karena itu wujud dari agama Hindu tidak diterima secara matang- matang oleh masyarajat tengger melainkan diolah dengan budaya setempat baik dari struktur Bahasa, Kebudayaan, Kepercayaan, organisasi sistem kemasyaraktan serta pengetahuan yang masih bersifat tradisonal. 30

Wujud dari bahasanya sendiri terlihat dari bahasa yang digunakan sehari-hari yang masih menggunakn bahasa jawa krama, bahkan pengucapan Salam pembuka berbeda dengan umat Hindu yang lainnya, jika umat Hindu kenggunkan kata "OM Swastiatsu" umat Hindu tengger menggunakan kata "Hong Ulun Bhasuki Langgeng” yang berarti (semoga Sang Hyang Widhi Wasa Senantiasa Memberikan Kedamaian, Kemakmuran, dan Kesehatan kepada kita semua). Hindu di tengger juga masih kental dengan adat istiadat serta budayanya yang berkembang menurut mereka warisan keluhur wajib dilestarikan dan lakukan sebagai wujud rasa penghormatan kedapa leluhur. Ajaran agama hindu juga tidak jauh beda dengan ajaran agama hindu pada umumnya sesuai dengan yang di terangkan dalam kitab Weda.

Selanjutnya agama Islam, Ajaran agama Islam masuk dan berkembang luas di kawasan tengger semenjak runtuhnya kerajaan majapahit dibawa kekuasaan demak, Islam di tengger memiliki sedikit perbedaan dengan Islam

30 Muslimin, "Alkuturasi Agama Hindu Di Indonesia, Al- Adyan, Vol 7 No. 2, Desember 2012: 67 
yang lain karena agama Islam yang berada di Tengger masih kental dengan adat dan budaya jawa. Sudah terlihat dari melakukan praktik keagamaannya terdapat beberapa hal yang berbeda seperti masih melibatkan dukun ketika melangsungkan perayaan umat hari besar Islam, upacara- upaca adat seperti karo-karo, unan- una, kasada dan lain- lain masih diikuti oleh masyarakat islam, selain itu juga upacara- upacara adat ini masih digunakan sebagai mediah dakwa islam. Penghormatan terhadap roh leluhur juga msih tetap dipertahankan oleh komunitas Islam tengger. Islam tidak harus ditempatkan pada konteks syariah saja tetapi juga tentang substansi Islam itu sendiri, dalam ajaran tasawuf yang bersandar pada al- Quran, hadits, setra praktik kehidupan Nabi Muhammad. Secara harfiyah tasawuf meyakini bahwa Rasulullah dalam mengajarkan Islam selalu menghormati warisan budaya leluhur tanpa harus menghilangkannya melainkan menyesuaikan dengan kondisi yang ada. ${ }^{31}$ Persoalan syariat tetap sesuai dengan ajaran Islam seperti melaksanakan sholat, puasa, dan ajaran- ajaran Islam yang lain. Islam di tengger termasuk Islam yang sinkretis karena didalam praktik ajaran agamanya terdapat perpaduan dari beberapa paham adat, budaya serta aliran kepercayaan agama lain. Selain agama Islam dan Hindu di daerah suku tengger juga terdapat ajaran agama Budha namun ketika masa orde baru ajaran agama budha di tengger di teliti pada tahun 1973 oleh kementrian agama melalui Dirjen Bimas Hindu-Budha. Ternya setelah diteliti masyarakat tengger masuk kedalam golongan agama Budha Mahayana, keputusan ini masih belum final karena pemuka agama Budha tengger tetap memutuskan bahwa mereka itu Budha (Tengger). Dan dikeluarkanlah Surat Keputusan No. 00/PHB-Jatim/Kept/III/73 tertanggalkan 6 Maret 1973.

\section{RUKUN DAN BUDAYA TOLERANSI SUKU TENGGER}

Suku Tengger adalah masyarakat yang masih terbilang agraris yang belum terjun langsung dengan budaya konsumeristik, dan materialis. Mereka akan tetap bertahan ditengah globalisasi zaman tetgantung dari para Dukun (Pemimpin Adat) yang memegang andil terpenting sebagai ahli waris kelestarian tradisi dan budaya di Tengger. $^{32}$ Meskipun mereka mendapatakan pengaruh baik dari segi agama, ekonimis, sosial, dan budaya pada dukun tengger masih tetap berperan aktif selaku pewaris tahta Majapahit dan Walndit. Meskipun keyakinan yang dipeluk masing-masing warga tidak sama namun ketika melakukan ritual adat tetap melestarikan

31 Aki Maksum, "Politik Identitas Masyarakat Tengger Dalam Mempertahankan Sistem Kebudayaan Dalam Hegemoni Islam Dan Kekuasaan”, El- Haraq, Vol 17, N0. 1 , Tahun 2015: 33

32 Sutarto, 1998 
tradisi yang berkembang diwilayah Tengger. Terbilang upacara adat yang dilakukan masih berbau ritual Hindu seperti: Kropak, Prapen (Tempat api dan Kemenyan), Genta, Serta Sampet (Kain selendang berwarna kuning biasanya digunakan oleh pendeta hindu pada masa kerajaan Majapahit). ${ }^{33}$ Semangat plularisme diwujudkan dengan mencintai budaya dan agama yang membuat mereka rentan terhadap munculnya sebuah konflik maupun ketimpangan sosial yang berdimensi etnis maupun keragaman agama.

Perkembangan teknologi yang kian melaju pesat menarik warga tengger untuk menccoba hal baru, tapi tidak terpengaruh oleh trend dan gaya hidup yang banyak di posting dimedia masa kebanyakan mereka memposisikan dirinya menjadi Wong Gunung ( warga masyarakat pegunungan) dari pada menjadi Wong Ngare (warga masyarakat dataran rendah yang hidup di perkotaan). Menurut mereka masyarakat perkotaan sangat berbeda dengan masyrakat pegunungan yang suka hidup sendiri dan jarang berkumpul secara bersama kecuali ada kegiatan yang sifatnya penting.

Rukun sudah menjadi ciri khas masyarakat tengger dalam berinteraksi, yang menjadikan rukunnya masyarakat ini adalah nilai- nilai toleransi sebagai pijakan hidup bersosial maupun beragama. Makna toleransi sendiri sebuah upaya dalam menciptakan kehidupan masyarakat yang harmonis dengan cara menghormati antar sesama, saling memmpercayai, saling kerja sama demi tercapainya masyarakat yang satu tanpa adanya ketimpanagn sosial. ${ }^{34}$ Sikap rukun yang diwariskan leluhur mewujudkan tatanan kondisi masyarakat tengger yang tentram bahkan hampir tidak ditemukannya konflik sosial maupun agama hal ini mencerminkan adanya perbedaan bukan suatu penghalang untuk memperkkoh persaudaraan. ${ }^{35}$ Masyarakat elit menggajarkan bahwa Yesus mengajarkan kasih sayang dan cinta, Nabi Muhammad mencontohkan rasa syukur atas nikmat Allah yang Maha Esa, Budha mengajarkan manusia untuk mengambil jalan tengah, dan Dewa mengajarkan manusia untuk melawan yang bathil dan menegakkan kebenaran. ${ }^{36}$ Menurut warga tengger "lebih baik banyak saudara dari pada banyak harta". ${ }^{37}$ Pepatah inilah yang menjadikan kerukunan warga ini. Pemupukan nilai-nilai ini terbukti dengan baik dilihat dari model hidup mereka yang penuh kehangatan dan ketentraman.

33 Wimmy Halim, "Identitas Wong Tengger Masyarakat Desa Ngandas: Refleksi Kebangsaan Atas Degradasi Identitas Dan Persatuan Nasional”, Proceeding AMIPEC, Vol 2, No 2, Tahun 2006

${ }^{34}$ Muhammad yasir, makna toleransi dalam al- qur'an, vol 22, no 2, tahun 2014

35 Fatmawati 2013

36 Nyoman S. Pendit, Nyepi: Kebangkitan, toleransi dan Kerukunan, (Jakarta: Gramedia Utama, 2001), 59

37 wawancara 
Masyarakat tengger juga mengenal adanya Welas Asih Pitu ( Tujuh cinta kasih sayang) ${ }^{38}$ diantaranya yaitu: Welas Asih Marang Bapa Kuasa (Tuhan), Welas Asih Marang Bapa Biyung (Orang Tua), Welas Asih Marang Ibu Pertiwi (Tanah Air), Welas Asih Marang Jiwa ( rasa jiwa), Welas Asih Marang Sepadane Urip (Sesama Manusia), Welas Asih Marang Sato Kewan (Binatang ), Welas Asih Marang Tandur Tetuwuh ( Tumbuh-Tumbuhan). Didalam tetuah ini masyarakat tengger ditekankan untuk berbuat baik kepada sesama manusia meskipun berbeda keyakinan tidak hanya manusia, alam, tumbuhan, dan juga hewanpun harus tetap dijaga inilah yang menyebabkan masyarakat tengger kental dengan kerukunannya.

Realisasi nilai - nilai keragaman tidak hanya perdana ini saja, bukti sejarah telah mencatat nilai-nilai kerukunan telah ada sedari dulu disuku ini. Terutama saat banyak Pelancong (pendatang baru ) yang berbondongbondong hadir ke wilayah ini, kekhawatiran dan kenyamanan telah muncul, sehingga untuk mempersatukan masyarakat ini para dukun- dukun berinisiatif menjadikan Upacara sebagai adat pemersatu lapisan elemen masyarakat tengger baik yang beragama Hindu, Budha, dan Islam. ${ }^{39}$ Seperti upacara Unan- Unan yaitu upacara terbesar bagi masyarakat tengger yang dilakukan dalam sewindu sekali, perhitungan sewindu ini berbeda dengan perhitungan saka, menurut kalender tengger sewindu itu bukan delapan tahun melainkan lima tahun sekali sesuai dengan perhitungan matahari yang setiap harinya terbit genap tiga puluh hari. Kalender tenggermenyebutkan bahwa tidak ada bulan dua puluh sembilan hari ataupun tiga puluh satu hari. Hal ini hampir sama dengan sistem penanggalan jawa yang hanya ada 5 hari yaitu: Pon, Wage, Keliwon, Pahing, Legi, sehingga satu minggu hanya terdapat lima hari dan sewindu hanya ditempuh dalam jangka waktu lima tahun. ${ }^{40}$ Mbah sindek (Sesepuh Dukun Desa Agrosari) mengatakan unan- unan berasal dari kata Hunan yang berarti nyaur banggi (membayar janji), dijelaskan dalan Makekat Junggring Saloko sebagai berikut:

"Leluhur kawula paringi pitedah wewarah kados ingkang kasebat wonten mekakat junggring saloka. Bilih Wong agung kiko dakso, dawuhaken Prabu Anom Sangge menyan kebak pelambung. Ki Ageng Ardi Anas Nambi Meru. Nyampuhaken putra wayah giri kusmo pikantuk nyi buring mbok

38 Harry Waluyo, Sistem Pemerintahan Tradisional di Tengger Jawa Timur. (Jakarta: Proyek Pengkajian dan Pembinaan Nilai-Nilai budaya, Direktorat Sejarah dan Nilai Tradisional, Direktorat JenderalKebudayaan, Departemen Pendidikan dan Kebudayaan, 1997), 86

39 Sudiro, "Legenda dan Religi Sebagai Media integritas Bangsa", HUMANIORA, Vo 8, No 1, Sebtember 2001, halaman 19-30

40 Wawancara dengan bapak budiono (Dukun Suku Tengger), di desa Agrosari pada: 25 November 2018 
wulanjar ingkang wonten sanggar ratu anom pemancil, ingkang nemurunaken yugo putu wonten saidenge poten tetenggere tanah pulo jawi".

Terdapat beberapa persyaratan yang harus di sediakan dalam upacara ini seperti: Gedang Ayu, Suruh Ayu, Jambe Ayu, dan yang paling terpenting Kerbau Putih. Ritual upacara ini dimulai dengan Rawa Tangkang (Pembacaan mantra suci dengan maskud meminta izin Kepada Bahu Rekso (Sebutan Pemimpin pada Masa Kerajaan) dan juga para roh leluhur yang membabat alas wilayah tengger. Kedua, Mapek (Ceremonial Pembukaan yang dihadiri oleh Perangkat Desa dan Jajaran Pemerintahan). Ketiga, Unan- Unan (ritual ini dilakukan dengan menyembelih kerbau putih yang dikhususkan kepada Tuhan sebagai ucapan rasa syukur atas nikmat alam yang telah diberikan sehingga kebutuhan hidup bisa tercukupi dan juga sebagai bentuk permohonan agar dijauhkan dari hal- hal yang berpengaruh negatif). Hal yang paling menarik disini adalah kerika usau penyembelihan Kerbau kulit dan tulang dibiarkan utuh hanya diambil bagian dagingya untuk ditusuk dan dihias diatas tubuh kerbau yang tengkurap lalu dihiasi dengan hasil bumi seperti gedhang ayu, sayur, dan buah- buahan yang lainnya lalu diarak dari lokasi penyembelihan menuju Punden Desa yang terdapat di Pure (tempat pertama kali didirikannya bangunan disuatu daerah). Malam harinya diadakan tasyakuran dengan menikmati sajian yang sudah dipersiapkan seluruh masyarakat tengger wajib mengadiri baik yang beragama Hindu, Budha dan Islam. Dalam perjamuan ini rasa kekeluargaan terasa nyata mereka merasa sama-sama punya cerita sejarah dan tatanan masyarakat yang sejajar. Karena semua berbaur menjadi satu tanpa sekat dalam bingkai kekeluargaan meskipun berbeda paham dan kepercayaan inilah bentuk dari sebuah kebersamaan dalam bingkai keberagam agamaan namun tetap keluarga.

Selain upacara unan-unan juga ada tradsi upacara Karo-Karo yaitu tradisi upacara paling besar yang dilakukan oleh masyarakat tengger baik Islam, Hindu, maupun Budha. Perayaan upacara ini tidak jauh berbeda dengan hari raya Idhul Fitri dan Idhul Adha, dimana Karo-karo ini dilakukan selama dua minggu tepat pada penanggalan tengger bulan kedua atau masyarakat tengger menyebutnya Bulan Karo. Tepat pada hari ini masyarakat tengger saling bermaaf-maafan dan juga berkungjung kesetiap rumah dimasyarakat setempat, yang paling terkesan dalam upacara ini yaitu terdapat penyembelian semua hasil ternak baik dari Ayam, Kambing, Babi, Sapi serta Kerbau untuk dinikmati dagingnya. Perayaan ini bagi masyarakat tengger sangat dinanti-nantikan karena sebagai hadiah dari kerja keras selama setahun baik bercocok tanam, bertani maupun bertenak. Seluhur 
lapisan masyarakat baik tua-muda, besar kecil, yang beragama Hindu, Islam, Budha membaur menjadi satu dalam suka cita perayaan karo. Perayaan karo ini terkesan semakin lengkap dan meriah jika hasil panen melimpah ruah. ${ }^{41}$

Dan yang terakhir Upacara Kasada atau Kasodoan yaitu upacara yang dilakukan pada tanggal 14, 15, 16 bukan kasodo bertepatan dengan bulan pernama yang sedang terpancar dan tampak di Lazuardi perayaan ini sekarang lebih dikenal dengan Yadnya Kasada. Yadnya Kasodo lebih tepatnya seperti hari Raya Kurban baik dari hasil bumi dan juga Hewan- hewan kurban sebagai bentuk pelestarian amanah leluhur suku tengger Raden Kusuma alias Kyai Kusuma alias Dewa Kusuma yang merupakan putra bungsuh dari Rara Anteng dan Jaka Seger. Kosodoan ini sebagai bentuk komunikasi anata suku Tengger dengan Tuhan serta Roh-roh leluhur yang menjaga kawasam tengger, interaksi ini dilakukan sebagai pewaris aktif tradisi ditengger. Ritual ini tidak hanya diikuti penganut agama Hindu saja tetapi juga Islam, Budha dan Kristen dengan melalui beberapa tahapan seperti ${ }^{42}$ : pertama, Pengambilan Mata Air Suci (air suci ini diambil dari Gunung Widodaren sebagai pelengkap pertama sebelum melakukan Yadnya Kasada, yang dibuat Ngelukat Umat (penyucian Jiwa Masyarakat Tengger)).${ }^{43}$ Kedua, Pembukaan Yadnya (dibuka oleh Parisada Hindu dan Juge seluruh Dukun suku Tengger baik dari Kabupaten Lumajang, Probolinggo, Malang, dan Pasuruan digelar di Ponten (Lautan Pasir Gunung Bromo). ${ }^{44}$ Ketiga, Upaca Kasada (ritual ini dimulai pada pukul 02.00 Wib-07.00 wib dengan berbagai rangkaian acara seperti persiapan acara, Membacakan KidungKidung, Ngelukat Umat (mensucikan Umat, Tempat Ibadah dan tempat para dewa), pembacaan kita suci Weda, Menceritakan Sejarah Kasada, Muspa (persembayangan), Doa Pasca Sembah, Pemilihan Calon Dukun, Acara Lelebuhan (Memasukkan) sesajen kedalam kawah Gunung Bromo, ) dalam Upacara inti kasodo ini banyak diikuti Umat Hindu karena jika ditelaah dari segi ritual banyak mengandung unsur Ajaran Hindu, jadi ketika ritual berlangsung umat selain Hindu hanya hadir untuk menyaksikan. Baru yang terakhir penghujung acara yaitu Pepujaan (Selamatan) acara ini di lakukan Poten masing-masing dengan menikmati hasil alam yang dipimpin oleh para Dukun serta sesepuh desa setempat). ${ }^{45}$

41 Sutarto, Komunitas Lokal Dalam Persefektif Perubahan Sosial Budaya: Suku Tengger, (Jember: Universitas Jember, 1997), 211- 212

42 Juli Astutik, Makna Ritual Upaca Kasada Dalam Persefektif Antropogi, Dalam Agama Tradisional, (Yogyakarta: Lkis, 2003), 128- 131

43 Mohammad Anas, "Telaah Metafisik Upacara Kasada, Mitos Dan Kearifan Hidup Dalam Masyarakat Tengger", Kalam : Jurnal Studi Agama Dan Pemikiran Islam, Vol 7, No 1, Juni 2013: 26

44 Ibid, 27

45 Ibid, 32 
Inilah wujud dari terbentuknya kerukunan umat beragama di Suku Tengger, dimana Adat dan budaya warisan leluhur yang menjadikan ketiga umat beragama yang berkembang di Tengger menjadi satu kesatuan dalam bingkai membangun umat beragama yang rukun dan damai. Mengkokohkan identitas sosial dengan mengembangkan nilai- nilai toleransi yang secara otomatis mengikat budaya- budaya yang ada di Indonesia menjadi persatuan. Ketika suku Tengger bisa bersatu, dan hanya sebagaian kecil negara di Indonesia yang mempu mengamalkan sila ke-3 didalam pancasila yaitu Persatuan Indonesia. Dimana persatuan adalah proses, dan kesatuan tidak tercapai tanpa adanaya proses. Dengan persatuan inilah, meskipun dipisahkan secara Regional, tidak mudah terpisahkan nilai- nilai seperti inilah yang dikembangakan masayarakat tengger untuk menegakkan adanya kerukunan umat beragama. Sikap seperti inilah yang harus di tiru seluruh lapisan masyarakat Indonesia untuk mempertahankan kesatuan di Indonesia menjadikan adat dan budaya sebagai pemersatu umat beragama.

\section{PENUTUP}

Masyarakat tengger dikenal sebagai masyarakat yang kental adat dan budayanya. Ditengah proses pradaban yang begitu panjang sangat terbukti bahwa masyarakat tengger tidak goyah untyk selalu memegang teguh warisan leluhur yang diturunkan secara turun temurun, berdasarkan paparan diatas membuktikan meskipun beragam agama baik Agama Hindu, Budha, dan Islam yang menduduki kawasan tengger tidak menggoyahkan sedikitpun rasa kekeluargaan yang ada justru keberagaman agama inlah yang makin memperkuat kerukukan antar umat begama didasari juga dengan memegang teguh adat istiadat serta budaya yang sudah berkembang untuk tetap menjaga kerukunan. Wujud dari kerukunan itu senditi terlaksana dengan adanya adat dan budaya seperti Upaca Karo, Upacara Unan-Unan, Upacara Kasada, Upacara Kelahiran serta upacara Kematian. Tidak ada perbedaan kasta yang mengikat karena di suku tengger tidak mengajarkan perbedaaan kasta yang ada hanya Wong Tengger (Masyarakat Suku Tengger).

Model kerukunan yang berbasic kebudayaan yang terdapat di suku tengger terletak pada Kabupaten Lumajang, Kabupaten Malang, Kabupaten Probolinggo, dan Kabupaten Pasuruan, yang menduduknya memeluk agama Hindu, Budha, Islam. Hal ini terjadi dikarenakan kearifan lokal yang masih terpelihara dengan baik melampaui ikatan- ikatan keagamaan, bagi mereka menghormati leluhur serta taat kepada Dukun yang paling penting agar memperoleh kehidupan yang harmonis dan tentram. Kondisi kerukuna ini terwujud dalam praktik- praktik sosial masyarakat Suku tengger, hubungan 
antar masyarakat pun juga terjalin dengan baik karena adanya sikap toleransi dalam bermasyarakat dengan baik yang dilandasi nilai- nilai budaya Tengger.

\section{DAFTAR PUSTAKA}

Ali Hisyam. Mohammad. 2015. Harmonisasi Lintas Agama Masyarakat Tengger. ISLAMICA Vol 10. N0 01. September

Ali. Mukti. 1997. Ilmu Perbandingan Agama, Dialog, Dakwah Dan Misi. Jakarta: Inis.

Ali. Mursid. 1999. Plularitas Sosial Dan Hubungan Antar Agama Bingkai Kulturall Dan Theologi, Kerukunan Hidup Umat Beragama. Jakarta: Badan Peneliti Pengembangan Agama Depag RI

Anas. Mohammad. 2013. "Telaah Metafisik Upacara Kasada, Mitos Dan Kearifan Hidup Dalam Masyarakat Tengger". Kalam : Jurnal Studi Agama Dan Pemikiran Islam. Vol 7. No 1. Juni

Aqil Al- Munawar. Said. 2005. Fiqh Hubungan Antar Agama. Jakarta: Ciputat Press

Astutik. Juli. 2003. Makna Ritual Upaca Kasada Dalam Persefektif Antropogi, Dalam Agama Tradisional. Yogyakarta: Lkis

Dangun. M. 1997. Kamus Besar Ilmu Pengetahuan. Jakarta: Lembaga Pengkajian Kebudayaan Nusantara

Darol Afia. Neng. 1999. Tradisi Dan Kepercayaan Lokal Bagi Beberapa Suku Yang Ada Di Indonseia.. Badan Litbang Agama Departemen Ri

Daya. Burhanuddin, Leonard Beck. Herman. 1992. Ilmu Perbandingan Agama Di Indonesia Dan Belanda. Jakarta: Inis

Djatiwijono.H.R. 1983. Dinamika Kerukunan Hidup Beragama Di Daerah. Jakarta: Maret

Halim.Wimmy. 2006. "Identitas Wong Tengger Masyarakat Desa Ngandas: Refleksi Kebangsaan Atas Degradasi Identitas Dan Persatuan Nasiona l", Proceeding AMIPEC, Vol 2. No 2.

Izza. Lathifatul. 2013 "Melihat Potret Harmonisasi Hubungan Antar Umat Beragama Di Indonesia”. Religi. Vol IX. No. 1. Januari

Kuntojiwo. 1998. Dari Kerukunan Ke Kerjasama, Dari Toleransi Ke Kooperasi. Jakarta: Pustaka Hidaya

Majid. Nurcholis. 2004. Fiqih Lintas Agama Membangun Masyarakat Inklusif Pluralis. Jakarta: Yayasan Wakaf Paramadina

Masum. Ali. 2015. "Politik Identitas Masyarakat Tengger Dalam Mempertahankan Sistem Kebudayaan Dalam Hegemoni Islam Dan Kekuasaan". El- Haraq. Vol 17. N0.1 
Mundar Soelaeman. M. 1987. Ilmu Sosial Dasar Teori Dan Konsep Ilmu Sosial. Bandung: ERSCO.

Muslimin. 2012. "Alkuturasi Agama Hindu Di Indonesia, Al- Adyan. Vol 7 No.

2. Desember

S. Pendit. Nyoman. 2001. Nyepi: Kebangkitan, Toleransi Dan Kerukunan. Jakarta: Gramedia Utama

Subandrijo. Bambang. 2000. Keselamatan Bagi Orang Jawa. Jakarta: Bpk Gunung Mulia

Sudiro. 2018. "Legenda Dan Religi Sebagai Media Integritas Bangsa". HUMANIORA Vo 8. No 1. September 2001

Sutarto. 1997. Komunitas Lokal Dalam Persefektif Perubahan Sosial Budaya: Suku Tengger. Jember: Universitas Jember

Sutarto. Ayu. 2007. Saya Orang Tengger, Saya Punya Agama: Kisah Orang Tengger Menemukan Agamanya. Jember: Kompyawisda

Sutarto. Ayu. 2008. Kamus Budaya Dan Religious. Jember: Lembaga Penelitian Universitas Jember

Suyono. Cart. R.P. 2009. Mitisisme Tengger. Yogyakarta: Lkis

Swidler. Leonard. 1990. The Dialogue, Ground Rules For Interreligious Dialogue. Davao City: Tp

Tri Haryonto. Joko. 2004. Kearifan Lokal Pendukung Kerukunan Beragama Pada Komunitas Tengger Malang Jatim. ANALISA Vol 21. No. 2

W. Hefner. Robert. 1985. Hindu Javanes And Tradition Islam. Princeton: Princeton University Perss

Waluyo. Harry. 1997. Sistem Pemerintahan Tradisional Di Tengger Jawa Timur. Jakarta: Proyek Pengkajian Dan Pembinaan Nilai-Nilai Budaya, Direktorat Sejarah Dan Nilai Tradisional, Direktorat Jenderalkebudayaan, Departemen Pendidikan Dan Kebudayaan.

Widyaprakoso. Samandhi. 1994. Masyarakat Tengger: Latar Belakang Daerah Taman Nasional Bromo. Jakarta: Kanisius

Yasi. Muhammad. 2014. Makna Toleransi Dalam Al- Qur'an. Vol 22. No 2

\section{Sumber Lain}

Al-Quran, Surat Al Hujurat Ayat 13

Wawancara Dengan Bapak Budiono (Dukun Suku Tengger), Di Desa Agrosari Pada: 25 November 2018 